\title{
SARKOIDOZĖS DIAGNOSTIKA IR GYDYMAS
}

\author{
MINDAUGAS VAITKUS, DOC. DR. DIANA BARKAUSKIENE
}

KMU PULMONOLOGIJOS IR IMUNOLOGIJOS KLINIKA

\begin{abstract}
Reikšminiai žodžiai: sarkoidozė, patogenezė, diagnostika, bronchų ir alveolių išplovos, tyrimai, infliksimabas, diagnostikos algoritmas.

Santrauka. Sarkoidozè - tai nežinomos kilmės daugiasistemė granuliominė liga. Organų pažeidimas paprastai būna be simptomų, o ir pati liga dažniausiai regresuoja savaime, bet gali progresuoti i lètinę fibrozę ir sunkų jivairių organų pažeidimą. Šiame straipsnyje aprašomi ligos diagnostikos aspektai, pateikiamas tyrimo algoritmas. Nemaža dèmesio skiriama sarkoidozés gydymo standartizavimui.
\end{abstract}

\section{APIBRÉŽIMAS}

Sarkoidozė - tai nežinomos kilmès daugiasistemė granuliominè liga, dažniausiai pasireiškianti 20-40 metų žmonėms. Nors priežastys nèra aiškios, tačiau patogenezèje pastebimi imuninès sistemos pokyčiai. Organų pažeidimas paprastai būna be simptomų, o ir pati liga dažniausiai regresuoja savaime, bet gali progresuoti i lètinę fibrozę ir sunkų ìvairių organų pažeidimą.

Sarkoidozè priklauso grupei intersticinių plaučių ligų, kurios paveikia plaučių audinio tvirtumą ar architektūrą, šiuo atveju - alveolių sienelę.

Sarkoidozè - įvairiai pasireiškianti liga. Ji gali pažeisti įvairius organus, dažniausiai apatinius kvèpavimo takus. Apie 5-10 proc. pacientų, sergančių sarkoidoze, miršta nuo sukeliamų komplikacijų, tokių kaip plaučių fibrozè, plautinè širdis, kvẻpavimo funkcijos nepakankamumas ar infekcijos.

\section{EPIDEMIOLOGIJA}

75 proc. sarkoidoze sergančių pacientų amžius viršija 40 metuc, kiek dažniau serga moterys, gali pasireikšti ir vaikams. Ligos paplitimas įvairiose šalyse nevienodas, pavyzdžiui, Amerikoje - 82 iš 100 tūkst. afroamerikiečių ir 8 iš 100 tūkst. baltujjų; Japonijoje $-2-3$ iš 100 tūkst., Švedijoje - 64 iš 100 tūkst., Anglijoje - 27 iš 100 tūkst. gyventojų.

Mirštamumas nèra didelis, bet afroamerikiečių, palyginti su kitomis etninèmis grupėmis, miršta daugiau. Dažniausia mirties priežastis yra kvėpavimo funkcijos nepakankamumas, išskirtinai Japonijoje - širdies nepakankamumas ar aritmijos dèl širdies sarkoidozès.

Genetinis polinkis sirgti sarkoidoze nèra patvirtintas. HLA B8 tipas susijęs su mazgine eritema, artritu ir ankstyva sarkoidozès diagnostika, HLA B13 tipas - su lètine ir užsitęsusia liga, o HLA B27 - manoma, su uveitu.

Yra pranešimų apie ligos pasireiškimą šeimose, bet aiškaus modelio tarp tèvų ir vaikų, brolių ir seseru tarpusavio santykio nèra. Sarkoidozė pasireiškia dvyniams, daugiau monozigotiniams nei dizigotiniams.

\section{PATOGENEZE்}

Etiologinis veiksnys, sukeliantis ligą, nežinomas. Manoma, jog ligos pagrindas - sutrikęs imuninis atsakas ị antigeną. Labiausiai paplitusi hipotezè, kad sarkoidozę sukelia retrovirusai. Atlikus PGR pacientams, sergantiems sarkoidoze, iš pašalintų limfmazgių mikobakterijos antigenas nenustatytas. Taigi sarkoidozės tuberkuliozè nesukelia. Atliktais tyrimais neirodyta, kad neatipinès mikobakterijos, Herpes virusai, ŽIV, autoimuniniai sutrikimai, berilis, pušų žiedadulkès, mineraliniai aliejai linkę sukelti sarkoidozę.

Ankstyvasis patofiziologinis sarkoidozės pasireiškimo požymis yra $\mathrm{T}$ limfocitų pagalbininkų (CD4+) ir makrofagų kaupimasis pažeistuose organuose, dèl to susiformuoja granuliomos, daugiausia plaučiuose. Pagrindinis sarkoidozès požymis - nekazeozinès granuliomos plaučių audinyje, kurios gali būti išsibarsčiusios aplink bronchovaskulinius limfos indus, tarpskiltinèse ir alveolių pertvarose, pleuroje (1 pav.). Pačios alveolès granuliomų nebūna pažeistos, jos santykinai normalios.

Patologiškai granulioma yra apribota uždegimo, sukeliamo $\mathrm{T}$ limfocituc ir gigantinių ląstelių. Gigantinès ląstelès yra 150-200 $\mu \mathrm{m}$ skersmens, sudarytos iš

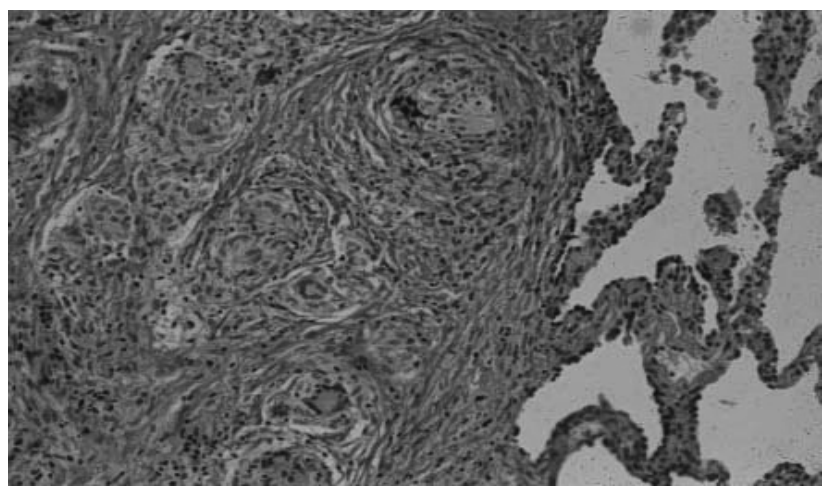

1 pav. INTERSTICINIS NEKAZEOZINIS GRANULIOMINIS UŽDEGIMAS 


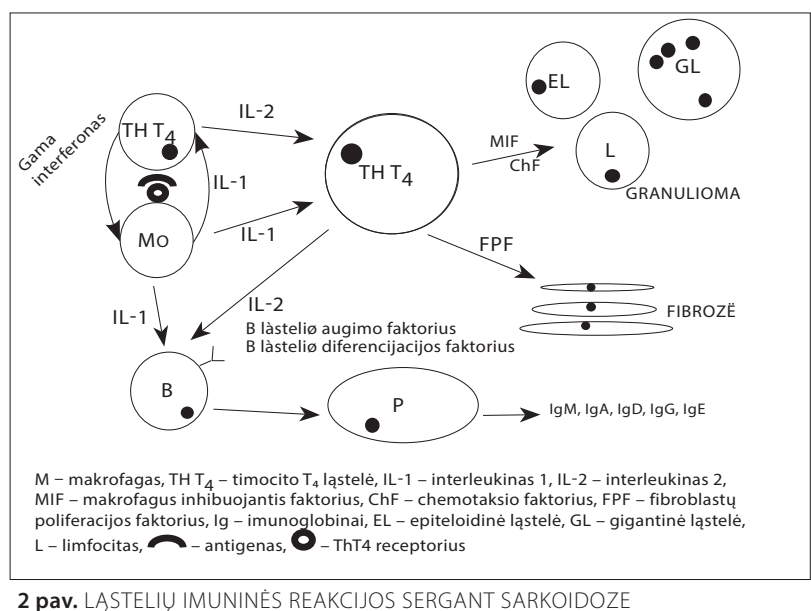

$20 \mu \mathrm{m}$ epitelioidinių ląstelių, kurios kilusios iš tarpusavyje susijungusių monocitų. Visa tai sudaro šerdị, kurią supa $\mathrm{T}$ limfocitai pagalbininkai, o šiuos - T limfocitai slopikliai.

Kazeozines ir nekazeozines granuliomas sukelia daug ligų, pavyzdžiui, ŽIV infekcija, AIDS, tuberkuliozé, netipiné mikobakterijų infekcija, beriliozè ar padidejusio jautrumo pneumonitas.

Ląstelių sąveika, sukelianti granuliomini uždegimą, vyksta taip:

1. Suaktyvėję alveolinis makrofagas išskiria interleukiną-1, kuris aktyvina ir stimuliuoja T limfocitų pagalbininku replikaciją plaučiuose.

2. Suaktyvejję $\mathrm{T}$ limfocitai pagalbininkai išskiria mediatorių interleukiną-2, kuris sužadina $\mathrm{T}$ ląsteliụ proliferaciją, monocituc chemotaksio faktorių ir $\gamma$ interferoną, dèl to formuojasi ir aktyveja vienabranduoliai (mononukleariniai) fagocitai.

3. Pažeistuose organuose $\mathrm{T}$ limfocitu pagalbininkų ir T slopikliuc santykis yra 10:1 (normalu 2:1). Taip paaiškinama santykinè limfopenija periferiniame kraujo tyrime (2 pav.).

1 lentelè. EKSTRATORAKALINĖS SARKOIDOZĖS FORMOS IR JU PASIREIŠKIMO DAŽNUMAS

\begin{tabular}{|c|c|}
\hline Organas & Dažnumas \\
\hline $\begin{array}{l}\text { Oda: mazginè eritema, Lupus pernio, poodiniai } \\
\text { mazgeliai }\end{array}$ & 25 proc. \\
\hline $\begin{array}{l}\text { CNS: ūminis ir lètinis meningitas, galvinių nervų } \\
\text { paralyžius, uveitas, regos nervo disko pabrinki- } \\
\text { mas, regos nervo atrofija, necukrinis diabetas }\end{array}$ & 5 proc. \\
\hline $\begin{array}{l}\text { Širdis: kardiomiopatijos, širdies nepakankamu- } \\
\text { mas, staigi mirtis, tachiaritmijos, perikarditas, } \\
\text { visiška širdies blokada }\end{array}$ & 5 proc. \\
\hline Virškinamasis traktas: abipusis parotitas & 10 proc. \\
\hline $\begin{array}{l}\text { Kepenys: granuliominis hepatitas su cholestaze, } \\
\text { hepatomegalija }\end{array}$ & $60-90$ proc. \\
\hline $\begin{array}{l}\text { Kraujas: anemija, trombocitopenija, splenome- } \\
\text { galija, eozinofilija }\end{array}$ & 15-40 proc. \\
\hline $\begin{array}{l}\text { Limfos sistema: kaklo, tarpuplaučio ar antkrum- } \\
\text { plio limfadenopatija }\end{array}$ & 80 proc. \\
\hline $\begin{array}{l}\text { Inkstai: nefrokalcinozè, nefrolitiazè, inkstų ne- } \\
\text { pakankamumas }\end{array}$ & Retai \\
\hline $\begin{array}{l}\text { Raumenų ir griaučių sistema: artralgija, artritas, } \\
\text { kaulu cistos }\end{array}$ & 5-25 proc. \\
\hline $\begin{array}{l}\text { Endokrininè sistema: hiperkalcemija, necukrinis } \\
\text { diabetas, hipopituitarizmas }\end{array}$ & Retai - 10 proc. \\
\hline
\end{tabular}

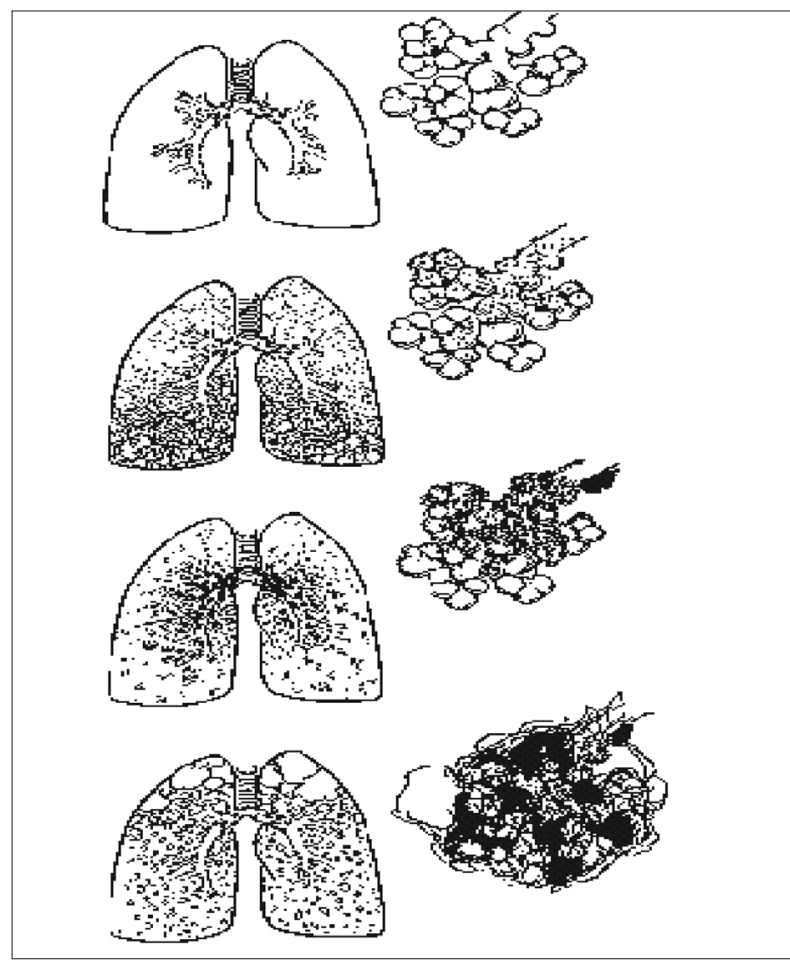

3 pav. PLAUČIIC AUDINIO KITIMAS NUO ALVEOLITO IKI GRANULIOMŲ IR FIBROZĖS SERGANT SARKOIDOZE

\section{KLINIKA}

Ligos klinika priklauso nuo to, kurie organai yra pažeisti granuliominio uždegimo. Dažniausiai pažeidžiami plaučiai, akys, oda ir limfmazgiai.

Progresuojančios granuliomos plaučiuose išveša ir susilieja. Sumažejus alveolių kvėpuojamajam plotui, pablogèja sąlygos vykti dujų difuzijai. Gydant plaučių granuliomas siekiama atitolinti plaučių fibrozę ir bronchektazių formavimąsi. Granuliominis angitas ir perivaskulinès granuliomos bei fibrozè padidina plaučių kraujagyslių pasipriešinimą ir taip vystosi plautine širdis.

Taigi progresuojanti sarkoidozė lemia plaučių fibrozę ir/ar plautinę širdị (3 pav.).

Kliniškai liga gali pasireikšti ekstratorakaliniais (1 lentelè) ar intratorakaliniais simptomais. Atskiro organo pažeidimas pasireiškia tam tikra klinika. Kadangi granuliominè liga yra sisteminé, sarkoidozè gali mègdžioti kitas ligas. 50 proc. atvejų liga esti besimptomè, 25 proc. - būdingi šie simptomai: karščiavimas, svorio mažèjimas, nuovargis, nerimas. Apie 50 proc. atvejų pokyčių nebūna, kitiems nustatoma pokyčių plaučiuose, kepenyse, limfmazgiuose, dažnai pažeidžiama širdis, CNS, dèl to ligonis miršta. Respiraciniai simptomai: dusulys ir sausas kosulys. Krūtinès skausmas, švokštimas, kraujo atkosejjimas labai reti simptomai. Jei atkosima kraujo, gydymas antibiotikais paprastai būna veiksmingas. Gausiai kraujo atkosima dèl bronchų arterijos aneurizmos plyšimo ir paprastai tokiais atvejais reikia bronchu arterijos embolizacijos ar chirurginès rezekcijos.

Dèl plautinès širdies esant hipoksemijai, kad būtú užkirstas kelias plautinès hipertenzijos vystymuisi ir progresavimui, reikia skirti deguonies. 
2 lentelè. SARKOIDOZĖS STADIJOS

\begin{tabular}{clc}
\hline Stadija & & $\begin{array}{c}\text { Pasireiškimo } \\
\text { dažnumas }\end{array}$ \\
\hline 0 & Akivaizdžiai normali rentgenograma & $<5$ proc. \\
\hline 1 & Abipusè plaučių vartų adenopatija & 50 proc. \\
\hline 2 & $\begin{array}{l}\text { Abipusė plaučių vartų adenopatija ir } \\
\text { infiltratai }\end{array}$ & 40 proc. \\
\hline 3 & $\begin{array}{l}\text { Infiltracija plaučiuose be adenopati- } \\
\text { jos }\end{array}$ & $5-10$ proc. \\
\hline
\end{tabular}

Hiperkalcemija pasireiškia dèl padidejjusios kalcio absorbcijos virškinamajame trakte. Normaliai 25-hidroksivitaminas D virsta kalcitrioliu inkstuose reguliuojant prieskydinių liaukuc hormonui - parathormonui. Padidejus kalcio kiekiui kraujyje, sustoja parathormono gamyba, kartu ir kalcitriolio. Esant granuliominei ligai, kalcitriolis gaminasi ne inkstuose, o suaktyvèjusiose vienbranduolèse ląstelèse (makrofaguose), plaučiuose ir limfmazgiuose. Normaliai monocitai/makrofagai kalcitriolio sintezę reguliuoja per grịžtamąji ryší, kad nebūtų perteklinès gamybos. Sergant granuliomine liga, monocitai gamina daugiau kalcitriolio ir yra atsparūs normaliam grizžtamojo ryšio reguliavimui, spejjama, dèl mediatoriaus $\gamma$ interferono. Vis dèlto hiperkalcemija pasireiškia tik 30-50 proc. pacientų, sergančių aktyvia sarkoidoze. Kalcitriolio metabolizmas gali būti sutrikęs ir esant normaliam kalcio kiekiui šlapime bei kraujyje.

\section{DIAGNOSTIKA}

Sarkoidozès diagnozè nustatoma kitų granuliominių ligų atmetimo būdu. I diferencinę diagnostiką turi būti ittrauktos šios ligos: tuberkuliozė, ŽIV infekcija, grybelinè infekcija, limfoma, seminoma, bronchogeninè karcinoma, beriliozè, netipinè mikobakteriju infekcija, padidejusio jautrumo pneumonitas, Wegener granuliomatozè ir kitos ligos, kurios gali būti susijusios su nekazeozinių granuliomų formavimusi. Plaučių audinio ar limfmazgio biopsija reikalinga ligai patvirtinti.

\section{Fizinis tyrimas}

Karščiavimas būna retai, dažniau Löffgren sindromo atvejais. Kiti fiziniu tyrimu nustatomi pokyčiai paprastai esti susiję su granuliomų pažeistų organų pokyčiais. Oda turi būti kruopščiai apžiūrima. Itvertinama, ar nèra limfadenopatijos, hepatomegalijos, splenomegalijos. Turi būti identifikuoti poodiniai ar raumeniniai mazgeliai. Jei pažeistos akys, apžiūrima su plyšine lempa. Pirštai gali būti pažeisti dèl kaulo pažeidimo, esant lètinei ligai pastebimi distrofiniai nagai. Üminis artritas, esant mazginei eritemai, turi būti atskiriamas nuo podagros.

\section{Laboratoriniai tyrimai}

Iprastiniais laboratoriniais tyrimais nustatoma anemija, limfopenija, hiperglobulinemija, hiperkalcemija ir/ar hiperkalciurija. Trombocituc skaičius retai sumažeja. Kepenų funkcijos rodikliai gali būti nedaug pakitę, paprastai padidèja alkoholinès fosfatazès kiekis. Jei yra ligos komplikacijų, kraujo dujose, bioche-

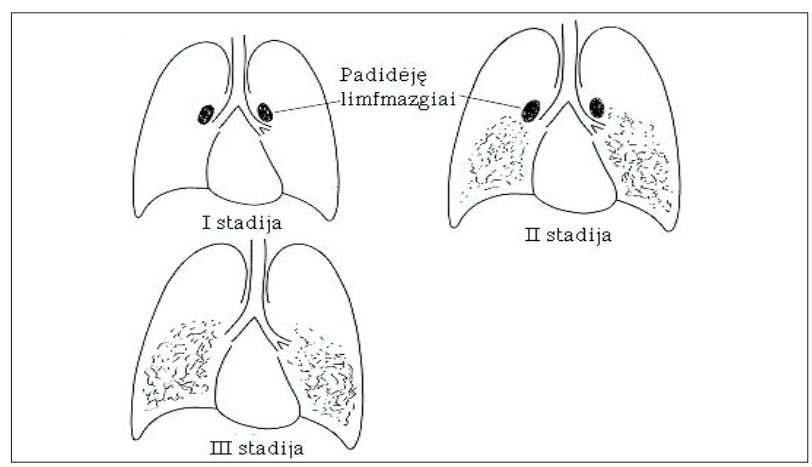

4 pav. SARKAIDOZĖS STADIJOS

miniame kraujo tyrime būna kvėpavimo funkcijos, inkstų funkcijos nepakankamumo požymių. Tiriant cerebrospinalinį skystị, kai yra neurosarkoidozè, nustatoma pleocitozè ir padidejęs kiekis baltymo. Angiotenzino konvertuojančio fermento padaugeja 60 proc. pacientų, sergančiu aktyvios formos liga. Vis dèlto tai nespecifinis tyrimas, nes šio fermento kiekis gali būti padidejęs sergant $C D$, hipertiroidizmu, ŽIV infekcija, kepenų ciroze, limfoangiomatoze, žarnų uždegimo liga netipine mikobakterine infekcija, asbestoze ar lètiniu nuovargio sindromu. Darant Kweim odos testą i poodi sušvirkščiama žmogaus, sergančio sarkoidoze, audinio suspensijos, gautos iš blužnies ar limfmazgio. Po 6-12 savaičių imama odos biopsija ir žiūrima, ar susidarẻ nekazeozinių granuliomų. Testo specifiškumas - 75 proc., bet jautrumas esant lètinei ligai - 65 proc., klaidingai teigiamų atsakymų -5 proc.

\section{Instrumentiniai tyrimai}

Esant širdies sarkoidozei, galimi ritmo ir laidumo sutrikimai.

Plaučių funkcijos testai rodo sumažèjusi plaučių tūrị. Hipoksemijos eiga iš lengvos ị sunkią rodo ventiliacijos ir perfuzijos $(\mathrm{V} / \mathrm{Q})$ neatitikimą bei difuzijos sutrikimą. Obstrukcijos plaučiuose atvejai sergant sarkoidoze yra reti, ji rodo granuliomu infiltraciją i smulkiuosius kvėpavimo takus. Plaučių funkcijos testais nustatomas pažeidimo laipsnis menkai siejasi su rentgenografiniu tyrimu ir histopatologija. Plaučių funkcijos testai neparodo ligos aktyvumo.

90 proc. pacientų, sergančiu sarkoidoze, randama klinikinių ar radiologinių pokyčių krūtinès ląstoje. Anksčiausiai rentgenogramoje matomas pakitimas yra abipusė plaučiuc vartų limfadenopatija su židininiais pokyčiais plaučiuose ar be jų. Skysčio pleuros ertmèje būna apie 5 proc. atvejų. Pneumotoraksas dèl smulkiu pūslelių plyšimo retas reiškinys, bet dažnas esant normaliam plaučiu audiniui. Jei nustatoma vienos pusès plaučio šaknies adenopatija, ir kitos šaknies adenopatija būna daugiau nei puse atvejų. Vienpusè plaučio adenopatija visai nebūdinga sarkoidozei (tik 5-10 proc. atvejų), o tai leidžia įtarti limfomos ar bronchogeninès karcinomos diagnozę. Rentgeninis sarkoidozès laipsnio nustatymas remiasi infiltracijos ir židinių išplitimu plaučiuose (2 lentelè, 4 pav.). 


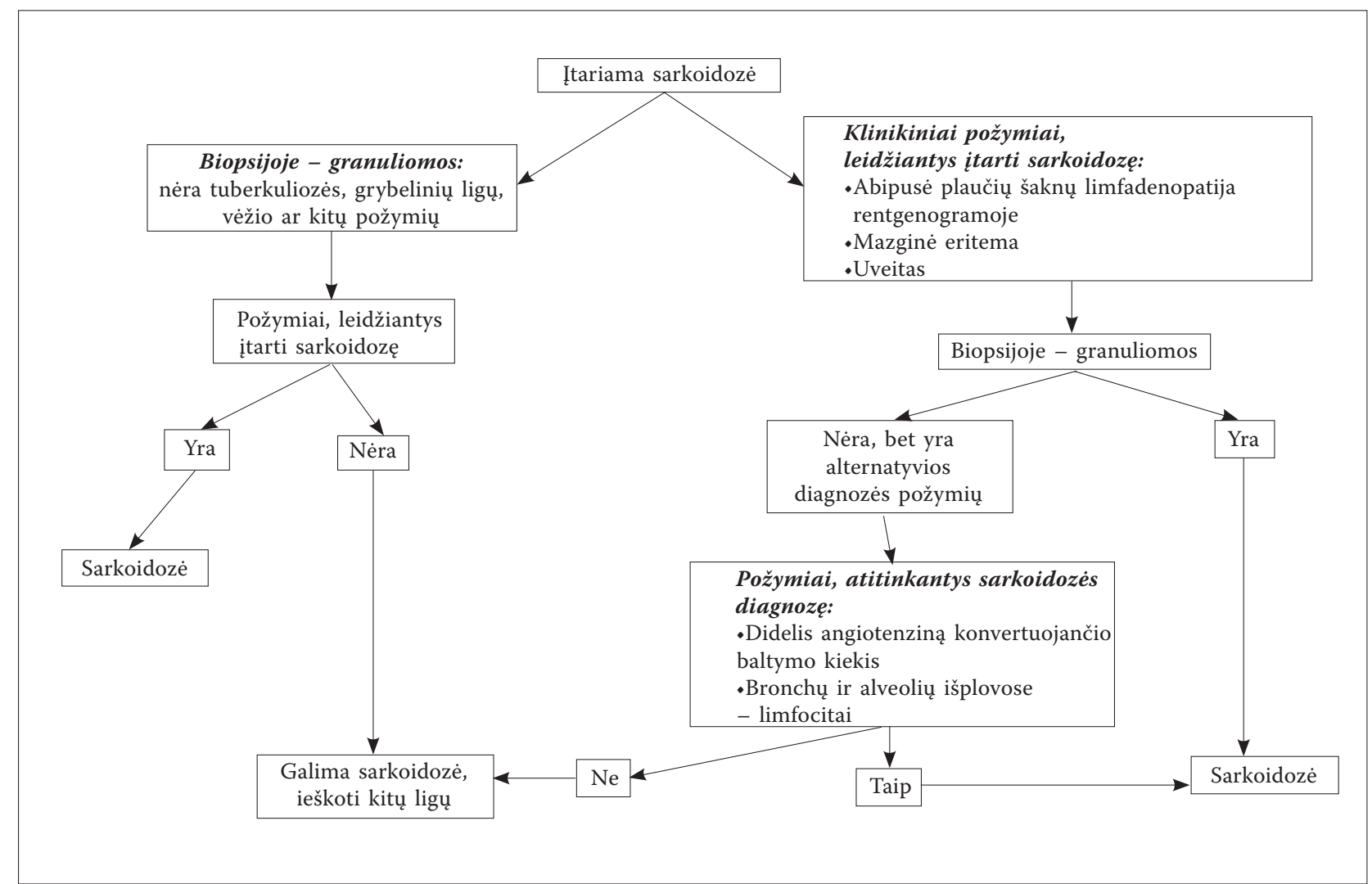

5 pav. SARKOIDOZĖS DIAGNOZAVIMO ALGORITMAS [5]

Paprasta arba aukštos rezoliucijos kompiuterine tomografija rodo būdingus židininius pokyčius, išsidèsčiusius limfagyslèse. Kai liga II stadijos, kompiuterine tomografija nustatoma apie bronchų kraujagyslių tinklus ir pleurą išsidèsčiusių infiltratų, jie gali kisti nuo apvalaus iki nelygaus židinuko ar alveolès sutankejjimo. Šie židinèliai rodo granuliomų sankaupas. Kompiuterinè tomografija labai svarbi nustatant sarkoidozès komplikacijas (fibrozinị mediastinitą, širdies pažeidimą ir kt.). Šis tyrimas labai jautrus nustatant subtilius intersticinius pokyčius, kurie paaiškina, kodèl rentgenogramoje esant tik minimaliems plaučių pokyčiams pacientas serga sunkia plaučių liga. Magnetinio rezonanso tyrimas taikomas nustatant CNS sarkoidozę.

Buvo manoma, kad fibrooptinès bronchoskopijos metu radus daugiau kaip 10 proc. $\mathrm{T}$ limfocitu, bus galima diagnozuoti ligą, bet klinikiniais tyrimais tai neįrodyta. Taigi bronchų ir alveolių išplovų (BAL) tyrimas nèra taikytinas sarkoidozei nustatyti, kaip buvo siūloma ankstesniuose literatūros šaltiniuose. Sarkoidozès atveju transbronchinė plaučiu audinio biopsija būna teigiama $60-90$ proc. atvejų. Tai viena iš procedūruc, per kurią galima gauti plaučių audinio tiksliai diagnozei nustatyti. Atviros plaučių audinio biopsijos dažniausiai neprireikia. Jei transbronchine biopsija liga nediagnozuojama, tarpuplaučio limfmazgio biopsija ligos diagnozè patvirtinama 8-90 proc. atvejų.

Plaučių nuskaitymas galiu 67 parodo uždegimo požymius ir lokalizaciją, bet tai nèra specifiška. Tyrimas tinkamesnis nustatant sarkoidozès pažeistus organus, pavyzdžiui, pažandinę liauką.
Kituc organų - odos, poodinių limfmazgių, tarpuplaučio limfmazgių (mediastinoskopijos metu), kepenų - biopsija nenaudinga, nebent ją atlikti lengva ir saugu arba reikia paneigti kitas ligas, pavyzdžiui, limfomą. Visada reikia atmesti ŽIV infekciją, kuri gali mėgžioti sarkoidozę. Literatūroje aprašomi 11 atvejų, kai pacientai sirgo sarkoidoze ir ŽIV, šešiems iš jų pirma pasireiškè sarkoidozè.

Galutinę sarkoidozès diagnozę patvirtina histologinis mėginys iš plaučio audinio ar limfmazgio. Simetrinis židinių pasiskirstymas ir padidejjimas nesusiliejant yra labai būdingas sarkoidozei, o ne neoplaziniam procesui. Sarkoidozès diagnozavimo algoritmas pateiktas 5 paveiksle.

\section{GYDYMAS}

50 proc. atveju sarkoidozè praeina savaime negydoma, dažniausiai po 6-17 mèn. nuo diagnozès nustatymo. Kai kurių tyrèjų duomenimis, 25 proc. ligonių savaiminè klinikine ir radiologinè remisija ívyksta greitai, kitiems 25 proc. reikia ilgesnio laiko iki jos, dar 25 proc. ligonių, kad būtų sukelta ligos remisija ir būklè stabilizuotusi, reikia gydyti, likusiems 25 proc. - nors ir gydoma, liga progresuoja.

Pirmaeiliai vaistai sergant sarkoidoze yra gliukokortikosteroidai. Gliukokortikosteroidai labai veiksmingi stabdant uždegimo procesą, kurị gali sukelti mechaniniai, cheminiai, infekciniai ir imuniniai veiksniai. Manoma, kad gliukokortikosteroidai slopina uždegimo geną, pavyzdžiui, interleukiną-1 ir tumoro nekrozės faktorių, molekulių ir receptorių adheziją, iš 
dalies veikia kaip interleukino-1 antagonistas. Sarkoidozès atveju gliukokortikosteroidai atkuria pusiausvyrą tarp susidariusių pirmo ir antro tipo $\mathrm{T}$ pagalbininku citokinų.

Kai kurie sarkoidoze sergantys pacientai yra atsparūs gliukokortikosteroidams, manoma, dèl per didelio alveoliu makrofagu tumoro nekrozès alfa faktoriaus atsipalaidavimo. Šis atradimas i̇rodè, kad pacientus, atsparius gliukokortikosteroidams, tikslinga gydyti antikūnais prieš tumoro nekrozès alfa faktorių, pavyzdžiui, infliksimabu.

\section{Gydymo gliukokortikosteroidais indikacijos}

Absoliučiosios:

- Progresuojantys plaučių ligos simptomai;

- Besimtomè plaučiu liga, kai lieka infiltracija ar vis labiau silpnèja plaučių funkcija;

- Širdies ligos;

- Neurologinès ligos;

- Akiu liga, kai vietinis gydymas neveiksmingas;

- Simptominé hiperkalcemija;

- Kitos simptominès / progresuojančios ne plaučiuc ligos.

Santykinès:

- Sisteminè plaučių liga;

- Artritas

- Kepenų sarkoidozè

- Sisteminis uždegimo atsako sindromas.

\section{Gliukokortikosteroidy dozavimas}

Pradedama gydyti 30-40 mg prednizolono doze kasdien, palaipsniui, per 6 ménesius, dozè sumažinama iki 7,5-10 mg (4 lentelè). Didesnès nei $1 \mathrm{mg} / \mathrm{kg}$ dozès skiriamos esant sunkios formos sarkoidozei: akių, širdies, nervų sistemos. Jei įvyksta atkrytis, paūmèja simptomai, blogèja plaučių funkcija, radiologiniai pokyčiai plaučiuose, prednizolono dozè didinama iki tokios, kad liga būtų suvaldyta, o vèliau mažinama iki tokios mažiausios, kad būtų didesnè nei vartota prieš atkrytị. Nustatyta, jog atkryčiai ịvyksta praejus 1-2 mėnesiams po steroidų vartojimo nutraukimo, o trims ketvirtadaliams pacientų, kurie steroidus liovèsi vartoti prieš 5 ir daugiau metú.
4 lentelè. GLIUKOKORTIKOSTEROIDU DOZAVIMAS GYDANT SARKOIDOZE

\begin{tabular}{lcc}
\hline & $\begin{array}{c}\text { Paros dozè } \\
(\mathbf{m g})\end{array}$ & $\begin{array}{c}\text { Trukmè } \\
\text { (sav.) }\end{array}$ \\
\hline Pradinis dozavimas' $^{1}$ & 40 & 4 \\
\hline & 30 & 4 \\
\hline & 20 & 4
\end{tabular}

Atsako ivertinimas po 3 ménesių ${ }^{2}$

\begin{tabular}{ccc}
\hline 15 & 13 \\
\hline 10 & 13 \\
\hline 7,5 & 13 \\
\hline Mažinti iki 0 & $13-26$
\end{tabular}

Dažniausiai skiriama prednizolono paros dozè $30-40 \mathrm{mg}$, t. y. $0,5 \mathrm{mg} / \mathrm{kg}$, didesnès kaip $1 \mathrm{mg} / \mathrm{kg}$ dozès skiriamos esant širdies ar nervy sistemos sarkoidozei.

Jei yra atsakas, nera fibrozinès ligos, neadekvačiu doziu ar büdingo atsparumo steroidams, pradedama pamažu dozę mažinti.

\section{Plaučių sarkoidozès gydymas}

Geriamųjų gliukokortikosteroidų poveikis vertintas daugeliu klinikinių nekontroliuojamųjų tyrimų. Ittikinamai įrodyta, jog gydymas sumažina granuliomini uždegimą. 5 lentelèje pateikiami duomenys 6 klinikinių atsitiktinių imčiu tyrimų, kuriais nustatyta, kad geriamieji gliukokortikosteroidai, vartojami 3-24 ménesius, smarkiai pagerina simptomus, biocheminius žymenis, plaučių funkciją ir krūtinès ląstos pokyčius. Deja, tyrimais nevertintas ilgalaikio gydymo gliukokortikosteroidais veiksmingumas, o nustatyti, ar ilgą laiką vartojant gliukokortikosteroidus galima sustabdyti plaučių fibrozès progresavimą, labai svarbu.

Britų krūtinès ląstos draugijos aprašytame tyrime dalyvavo 149 sarkoidoze sergantys pacientai, kuriems rentgenu buvo nustatyta plaučiu parenchimos pokyčiu. Po pradinio 6 mènesiu stebejjimo 33 pacientams dèl varginančių simptomų skirta vartoti gliukokortikosteroidų, 58 nustatytas savaiminis radiologinis pagerejjimas. Kiti 58 ligoniai gydyti gliukokortikosteroidais (1 ménesi $30 \mathrm{mg}$ paros doze, 1 ménesi $20 \mathrm{mg}, 1 \mathrm{mè-}$ nesi $15 \mathrm{mg}$ ir 9 ménesius $10 \mathrm{mg}$ per parą, per kitus 6 mènesius dozè mažinta). Palyginti su stebimuju grupe, pacientams, kurie vartojo gliukokortikosteroidus 5 metus, labai pagerejjo plaučių funkcija (apie 10 proc. padidejo forsuotas iškvejpimo tūris per pirmą sekundę (FEV1) ir gyvybinè plaučiu talpa (VC). Stebimųjų grupeje apie 20 proc. pacientų liga progresavo ir jiems skirta gliukokortikosteroidų.

5 lentelè. GYDYMO GERIAMAISIAIS GLIUKOKORTIKOSTEROIDAIS REZULTATAI, NUSTATYTI KLINIKINIAIS ATSITIKTINIU IMČIU TYRIMAIS

\begin{tabular}{|c|c|c|c|c|c|c|}
\hline Tyrejas & James & Israel & Roth & Selroos & Zaki & Pietinalho \\
\hline $\begin{array}{l}\text { Gydymas / kontrolè } \\
\text { (n) }\end{array}$ & $\begin{array}{l}27 \text { prednizolonu } \\
(20 \mathrm{mg}) / 24 \\
\text { placebu }\end{array}$ & $\begin{array}{l}41 \text { prednizolonu }(15 \mathrm{mg}) \text { / } \\
42 \text { placebu }\end{array}$ & $\begin{array}{l}54 \text { prednizolonu ( } 40 \\
\mathrm{mg} \text { ) / } 38 \text { negydyta }\end{array}$ & $\begin{array}{l}19 \text { metilprednizolo- } \\
\text { nu ( } 32-4 \mathrm{mg}) / 57 \\
\text { placebu }\end{array}$ & $\begin{array}{l}77 \text { prednizolonu } \\
(40-20 \mathrm{mg}) / 18 \\
\text { negydyta }\end{array}$ & $\begin{array}{l}91 \text { prednizolonu }(20-10 \mathrm{mg}) / \\
94 \text { placebu }\end{array}$ \\
\hline $\begin{array}{l}\text { Gydymas, gydymo } \\
\text { tąsa (mèn.) }\end{array}$ & 6,0 & 3, 12-132 (vidurkis - 60) & $\begin{array}{l}\text { 6/12, 60-168 } \\
\text { (vidurkis }-96 \text { ) }\end{array}$ & 7,48 & Jokio skirtumo & 3,60 \\
\hline Rezultatas & $\begin{array}{l}\text { Radiologinis } \\
\text { pagerejimas po } 6 \\
\text { mènesių }\end{array}$ & Nebuvo skirtumo & $\begin{array}{l}\text { Per } 2 \text { metus radiolo- } \\
\text { ginis pagerèjimas; tę- } \\
\text { siant gydymą skirtumo } \\
\text { nebuvo }\end{array}$ & $\begin{array}{l}\text { Radiologinis pageré- } \\
\text { jimas, VC ir DLCO } 7 \\
\text { méneși, tęsiant - skir- } \\
\text { tumo nebuvo }\end{array}$ & Jokio skirtumo & $\begin{array}{l}\text { Pagerèjimas AKF; radiologinis } \\
\text { pageréjimas } 3 \text { ir } 6 \text { mèneși, bet } \\
\text { tęsiant - ne; pagerèjimas VC ir } \\
\text { DLCO } 18 \text { ir } 60 \text { mènesi }\end{array}$ \\
\hline Pastabos & Netęsta & $\begin{array}{l}24 \text { proc. poveikio gr. ir } 38 \\
\text { proc. placebo gr. pacientu } \\
\text { jvyko atkrytis ar liga pro- } \\
\text { gresavo tęsiant gydymą }\end{array}$ & $\begin{array}{l}\text { Tęsiant gydymą apie } \\
50 \text { proc. pacientų mire }\end{array}$ & $\begin{array}{l}\text { Tęsiant gydymą apie } \\
50 \text { proc. pacientų } \\
\text { miré }\end{array}$ & $\begin{array}{l}\text { Dauguma pacie- } \\
\text { ntų tęsiant miré; } \\
\text { nėra duomenų }\end{array}$ & $\begin{array}{l}\text { Radiologinis pagerejimas plau- } \\
\text { čiuose nustatytas parenchimos } \\
\text { infiltracijos atvejais }\end{array}$ \\
\hline
\end{tabular}


6 lentelè. GYDYMO INHALIUOJAMAISIAIS GLIUKOKORTIKOSTEROIDAIS REZULTATAI, NUSTATYTI KLINIKINIAIS ATSITIKTINIŲ IMČIŲ TYRIMAIS

\begin{tabular}{|c|c|c|c|c|c|c|}
\hline Tyrèjas & Erkila & Milman & Du Bois & McGrath & Baughman & Albarts \\
\hline $\begin{array}{l}\text { Gydymas / kontrolè } \\
\text { (n) }\end{array}$ & $\begin{array}{l}9 \text { budezonidu } \\
(800 \mu \mathrm{g}) \\
/ 10 \text { placebu }\end{array}$ & $\begin{array}{l}9 \text { budezonidu } \\
(1200 \mu \mathrm{g}) / 12 \\
\text { placebu }\end{array}$ & $\begin{array}{l}21 \text { fliutikazonu } \\
(2000 \mu \mathrm{g}) / 22 \\
\text { placebu }\end{array}$ & $\begin{array}{l}15 \text { beklametazonu } \\
(1600 \mu \mathrm{g}) / 12 \\
\text { placebo }\end{array}$ & $\begin{array}{l}10 \text { fliutikazonu } \\
(1600 \mu \mathrm{g}) / 11 \\
\text { placebu }\end{array}$ & $\begin{array}{l}22 \text { budezonidu }(1200 \mu \mathrm{g}) / \\
25 \text { placebu }\end{array}$ \\
\hline $\begin{array}{l}\text { Gydymas, gydymo } \\
\text { tąsa (mèn.) }\end{array}$ & $2-, 5,0$ & 12,6 & $6,7-8$ & 6,0 & 12,0 & 6,6 \\
\hline Rezultatas & $\begin{array}{l}\text { Pagerèjo serume } \\
\text { beta } 2 \text { mikroglo- } \\
\text { bulino, BAL skysčio } \\
\text { limfocitozé }\end{array}$ & Jokio skirtumo & Jokio skirtumo & Jokio skirtumo & Jokio skirtumo & $\begin{array}{l}\text { Simptomy ir VC pagereji- } \\
\text { mas (apie } 8 \text { proc.) }\end{array}$ \\
\hline Pastabos & $\begin{array}{l}\text { Nustatyta nauju } \\
\text { atsparumo steroi- } \\
\text { dams atvejų }\end{array}$ & $\begin{array}{l}\text { Apie } 40 \text { proc. } \\
\text { tiriamuju pradejjo } \\
\text { vartoti geriamuo- } \\
\text { sius gliukokorti- } \\
\text { kosteroidus }\end{array}$ & $\begin{array}{l}\text { Apie } 75 \text { proc. } \\
\text { tiriamuju pradejjo } \\
\text { vartoti geriamuo- } \\
\text { sius gliukokorti- } \\
\text { kosteroidus }\end{array}$ & $\begin{array}{l}\text { Nèra duomenų } \\
\text { apie geriamujų } \\
\text { gliukokortikoidy } \\
\text { vartojimą }\end{array}$ & $\begin{array}{l}\text { Visi pacientai } \\
\text { pradèjo vartoti } \\
\text { prednizoloną po } \\
20 \text { mg per parą } 4 \\
\text { savaites prieš tyri- } \\
\text { mo pabaigą }\end{array}$ & $\begin{array}{l}\text { Nustatyta nauju atsparumo } \\
\text { steroidams atveju }\end{array}$ \\
\hline
\end{tabular}

Taigi kol kas nėra ilgų klinikinių atsitiktinių imčių tyrimų, kuriais visiškai aiškiai būtų nustatyti ilgalaikio gydymo gliukokortikosteroidais padariniai.

Plaučių sarkoidozè yra liga, kurios patologinis procesas vyksta limfagyslèse, bet iš dalies ir apie bronchų kraujagyslių tinklus, todèl inhaliuojamųjų gliukokortikosteroidų vartojimas būtų tinkamas gydymo metodas. Be to, inhaliuojamieji gliukokortikosteroidai sukelia mažiau nepageidaujamų reakcijų.

Atlikti šeši klinikiniai atsitiktinių imčių kontroliuojamieji tyrimai, kuriais vertintas sarkoidozès gydymas inhaliuojamaisiais gliukokortikosteroidais (6 lentelè). Keturiais iš jų nenustatyta, kad inhaliuojamieji gliukokortikosteroidai naudingi. Alberts ir kolegų didelio klinikinio atsitiktiniu imčiu tyrimo duomenimis, 6 ménesius gydant inhaliuojamaisiais gliukokortikosteroidais labai pagerejja simptomai ir gyvybinė plaučių talpa, bet angiotenzina konvertuojančio fermento kiekio kraujyje tyrimo, plaučių difuzijos su anglies monoksidu (CO) ar rentgeninių krūtinès ląstos tyrimų rezultatai nepagerejja.

\section{Kitų organų sarkoidozès gydymas}

Širdies sarkoidozé. Šios lokalizacijos sarkoidozè lemia daugiausia mirčiuc, todèl kiekvienas naujas pacientas, kuriam ịtariama sarkoidozé, turètų būti apklausiamas dèl širdies sukeliamų negalavimų, atliekama EKG. Širdies sarkoidozè yra absoliučioji indikacija gydyti gliukokortikosteroidais. Trijų retrospektyviųjų didelès apimties tyrimų duomenimis, jais gydant ligos prognozé būna gera. İdomu tai, kad miokardo granuliomos yra daug jautresnès gliukokortikosteroidams nei kitu organų.

Nervu sistemos sarkoidozè. Dažniausia lokalizacija - galvos smegenų pamatas, bet gali būti ir periferineje nervu sistemoje, sukelti paralyžių. Nervų sistemos sarkoidozė yra absoliučioji indikacija gydyti gliukokortikosteroidais. Allen su kolegomis nustaté, jog 16 (84 proc.) iš 19 atvejų gliukokortikosteroidai buvo veiksmingi.

Akiu sarkoidozè. Sarkoidozès pažeista gali būti bet kuri akies vieta. Dažniausia ligos išraiška - uveitas. Priekinis uveitas gali baigtis be komplikacijų, turètų būti gydomas gliukokortikosteroidais ir midriaziniais lašais ị akis. Užpakalinis uveitas dažniau būna lètinis ir gali sukelti rimtų regejjimo sutrikimų. Ši ligos forma gydoma gliukokortikosteroidu injekcijomis $\mathfrak{i}$ ir aplink aki arba sisteminio poveikio gliukokortikosteroidais, kad ligoniui nesutriktų regejjimas.

\section{Alternatyvūs vaistai sarkoidozei gydyti}

Sarkoidozei gydyti vartojami ịvairūs imunosupresantai ir imunomoduliatoriai - jie yra alternatyvūs vaistai. Plaučiuc sarkoidozės atveju vartojami metotreksatas, hidrochlorokvinas ir azatioprinas. Peržiūrèjus tyrimų duomenis paaiškejo, kad norimų rezultatų nepasiekta nei mažinant simptomus, nei gerinant plaučių funkciją ar radiologinius krūtinès ląstos pokyčius, išskyrus gydymą leflunomidu. Vartojant ši vaistą sarkoidozei gydyti poveikis buvo veiksmingesnis, o šalutinių reiškinių mažiau nei gydant metotreksatu.

Kai yra atsparumas gliukokortikosteroidams, kaip alternatyvūs vaistai, kartu su mažomis gliukokortikosteroidu dozèmis (gliukokortikosteroidus tausojantis vaistas) vartojami metotreksatas ir azatioprinas. Taip gydomi pacientai, kurie reaguoja i prednizoloną, bet jaučiasi blogai dèl šalutinio poveikio, kurị sukelia didelès gliukokortikosteroidų dozès.

Imunosupresantų dažniausiai skiriama gydant ne plaučių sarkoidozę. Pavyzdžiui, metotreksatas gali būti vartojamas gydant uveitą ir kaip pirmaeilis gydant nervų sistemos sarkoidozę, kai ji atspari gliukokortikosteroidams.

Antimaliariniai vaistai, chlorokvinas ir hidrochlorokvinas (mažiau kenkia akims nei chlorokvinas), yra veiksmingesni gydant odos ir gleivinių sarkoidozę nei plaučiuc. Talidomidas itin efektyvus esant Lupus pernio.

Gydymas infliksimabu, antikūnu prieš tumoro nekrozès faktorių, veiksmingiausias atsparios sarkoidozès atveju. Gydant akių sarkoidozę, infliksimabas buvo efektyvus 7 iš 7 atvejų.

Alternatyvus gydymas imunosupresantais pradedamas, kai gydant gliukokortikosteroidu poveikis per silpnas ar kai kasdienè prednizolono dozė viršija 20 mg. Tokiais atvejais kaip pirmaeilis vaistas skiriamas 
metotreksatas. Kai kurių tyrèjų duomenimis, $15 \mathrm{mg}$ per savaitę doze vartojamas metotreksatas yra gana efektyvus ir gerai toleruojamas stebint kepenų fermentų pokyčius. Pacientams, kurie netoleruoja prednizolono sukeliamų šalutinių reakcijų, metotreksato skiriama vartoti kaip gliukokortikosteroidus tausojančio vaistas, mažinant prednizolono dozes. Jei sarkoidozè atspari gliukokortikosteroidams ir metotreksatui, gydoma infliksimabu: $5 \mathrm{mg} / \mathrm{kg}$ pirmą, antrą ir šeštą savaitę, kartojama kas 8 savaites, iš viso 7 dozès. Kadangi infliksimabas labai toksiškas ir gali sukelti alerginių reakcijų, anafilaksiją, infuzijos laiku pacientas turi būti atidžiai stebimas. Trims ketvirtadaliams taip gydomų pacientu išsivysto širdies nepakankamumas, kitos galimos šalutinès reakcijos: galvos svaigimas, šlapinimosi sutrikimai, nuovargis, užkimimas, galvos skausmas.

\section{LITERATŪRA}

1. Baughman RP, Lower EE, Du Bois RM. Sarcoidosis. Lancet. 2003;361:11111118.

2. American Thoracic Society, European Respiratory Society. Idiopathic pulmonary fibrosis: diagnosis and treatment.

3. American Thoracic Society/European Respiratory Society InternationaMultidisciplinary Consensus Classification of the Idiopathic Interstitia Pneumonias. Am J Respir Crit Care Med 2002; 165: 277-304.

4. Collard H, Ryu J, Douglas W, et al. Combined corticosteroid and cyclophosphamide therapy does not alter survival in idiopathic pulmonary fibrosis. Chest 2004; 125: 2169-2174.

5. Flaherty KR, Mumford JA, Murray S, et al. Prognostic implications of physiologic and radiographic changes in idiopathic interstitial pneumonia. Am J Respir Crit Care Med 2003; 168: 543-548.

6. Newman LS. Aetiologies of sarcoidosis. Eur Respir Mon 2005; 32: 23-48.

7. Ho LP, Urban BC, Thickett DR, Davies RJ, McMichael AJ. Deficiency of a subset of T-cells with immunoregulatory properties in sarcoidosis. Lancet 2005; 365: 1062-1072.

8. Valentonyte R, Hampe J, Huse K, et al. Sarcoidosis is associated with truncating splice site mutation in BTNL2. Nat Genet 2005; 37: 357-64.

9. Grutters JC, Sato H, Welsh KI, du Bois RM. The importance of sarcoidosis genotype to lung phenotype. Am J Respir Cell Mol Biol 2003; 29: S59S62.

10. Spagnolo P, Renzoni EA, Wells AU, et al. C-C chemokine receptor 2 and sarcoidosis: association with Lofgren's syndrome. Am J Respir Crit Care Med 2003; 168: 1162-1166.

11. Moeller DR. Treatment of sarcoidosis - from a basic science point of view. J Intern Med 2003; 253: 31-40.

12. Kruit A, Grutters JC, Ruven HJT, et al. TGF beta polymorphisms in sarcoidosis patients with and without pulmonary fibrosis. Sarcoidosis Vasc Diffuse Lung Dis 2005;22: 253 .

13. Ziegenhagen MW, Rothe ME, Zissel G, Mu“ Iler-Quernheim J. Exagger ated TNFa release of alveolar macrophages in corticosteroid resistant sarcoidosis. Sarcoidosis Vasc Diffuse Lung Dis 2002; 19: 185-190.

14. Drent $M$, van den Berg $R$, Haenen GR, van den Berg $H$, Wouters EF, Bast $A$. NF-kB activation in sarcoidosis. Sarcoidosis Vasc Diffuse Lung Dis 2001 18: $50-56$.

15. Rutherford RM, Kehren J, Staedtler F, et al. Functional genomics in sarcoidosis - reduced or increased apoptosis? Swiss Med Wkly 2001; 131: 459-70.

16. Conron $\mathrm{M}$, Bondeson J, Pantelidis $\mathrm{P}$, et al. Alveolar macrophages and $\mathrm{T}$ cells from sarcoid, but not normal lung, are permissive to adenovirus in fection and allow analysis of NF-kB-dependent signaling pathways. Am J Respir Cell Mol Biol 2001; 25: 141-149.

17. Pietinalho A, Tukiainen $P$, Haahtela $T$, Persson $T$, Selroos O. Early treatment of stage II sarcoidosis improves 5-year pulmonary function. Chest 2002; 121: 24-31.

18. Paramothayan NS, Lasserson TJ, Jones PW. Corticosteroids for pulmonary sarcoidosis. Cochrane Database Syst Rev 2005; CD001114.

19. Paramothayan S, Jones PW. Corticosteroid therapy in pulmonary sarcoidosis: a systematic review. JAMA 2002; 287: 1301-1307.

20. Reich JM. Mortality of intrathoracic sarcoidosis in referral vs populationbased settings: influence of stage, ethnicity, and corticosteroid therapy. Chest 2002; 121: 32-39.

21. McGrath D, Wells AU, Desai SR, et al. Efficacy, safety and tolerability of $3 M$

\section{SARCOIDOSIS DIAGNOSTIC AND TREATMENT}

\author{
MINDAUGAS VAITKUS, DIANA BARKAUSKIENÉ \\ DEPARTMENT OF PULMONOLOGY AND IMMUNOLOGY \\ KAUNAS UNIVERSITY OF MEDICINE
}

Key words: sarcoidosis, diagnostic, biopsy, staging, treatment, infliximab, algorithm.

Summary. Sarcoidosis is an inflammatory disease characterized by granulomas (small rounded outgrowths made up of blood vessels, cells and connective tissues) that can produce many different symptoms. It is generally a chronic disease, lasting for several years or a lifetime. Pulmonary sarcoidosis can cause loss of lung volume. This actually distorts the structure of the lungs and can interfere with breathing, especially the ability to exchange oxygen in the lungs. Diagnosis usually is first suspected because of pulmonary involvement and is confirmed by chest x-ray, biopsy, and exclusion of other causes of granulomatous inflammation.

HFA-134a beclomethasone dipropionate in pulmonary sarcoidosis. Am J Respir Crit Care Med 2002; 165: A495.

22. Shorr AF, Torrington KG, Hnatiuk OW. Endobronchial involvement and airway hyperreactivity in patients with sarcoidosis. Chest 2001; 120: 881-886.

23. Hoitsma E, Marziniak M, Faber CG, et al. Small fibre neuropathy in sarcoidosis. Lancet 2002; 359: 2085-2086.

24. Yazaki $Y$, Isobe $M$, Hiroe $M$, et al. Prognostic determinants of long-term survival in Japanese patients with cardiac sarcoidosis treated with prednisone. Am J Cardiol 2001; 88:1006-1010.

25. Kato Y, Morimoto S, Uemura A, Hiramitsu S, Ito T, Hishida H. Efficacy of corticosteroids in sarcoidosis presenting with atrioventricular block. Sarcoidosis Vasc Diffuse Lung Dis 2003; 20: 133-137.

26. Chiu CZ, Nakatani S, Zhang G, et al. Prevention of left ventricular remodeling by long-term corticosteroid therapy in patients with cardiac sarcoidosis. Am J Cardiol 2005; 95: 143-146.

27. Chapelon-Abric $C$, de Zuttere $D$, Duhaut $P$, et al. Cardiac sarcoidosis: a retrospective study of 41 cases. Medicine (Baltimore) 2004; 83: 315334.

28. Allen RK, Sellars RE, Sandstrom PA. A prospective study of 32 patients with neurosarcoidosis. Sarcoidosis Vasc Diffuse Lung Dis 2003; 20: 118125.

29. Ohara K, Judson MA, Baughman RP, Clinical aspects of ocular sarcoidosis. Eur Respir Mon 2005; 10, 32: 188-209.

30. Paramothayan S, Lasserson T, Walters EH. Immunosuppressive and cytotoxic therapy for pulmonary sarcoidosis. Cochrane Database Syst Rev 2003; CD003536.

31. Baughman RP, Lower EE. Leflunomide for chronic sarcoidosis. Sarcoidosis Vasc Diffuse Lung Dis 2004; 21: 43-48.

32. Baughman RP, Lower EE, Therapy for sarcoidosis. Eur Respir Mon 2005; 32: 301-315.

33. Hoitsma E, Sharma OP, Neurosarcoidosis. Eur Respir Mon 2005; 32: 164187.

34. Baughman RP, Judson MA, Teirstein AS, Mo" Iler DR, Lower EE. Thalidomide for chronic sarcoidosis. Chest 2002; 122: 227-232.

35. Baughman RP, Lower EE. Infliximab for refractory sarcoidosis. Sarcoidosis Vasc Diffuse Lung Dis 2001; 18: 70-74.

36. Yee AM, Pochapin MB. Treatment of complicated sarcoidosis with infliximab anti-tumor necrosis factor-a therapy. Ann Intern Med 2001; 135: 27-31.

37. Baughman RP, Bradley DA, Lower EE. Infliximab in chronic ocular inflammation. Int J Clin Pharmacol Ther 2005; 43: 7-11.

38. Baughman RP, Lower EE, Bradley DA, Raymond LA, Kaufman A. Etanercept for refractory ocular sarcoidosis: results of a double-blind randomized trial. Chest 2005; 128: 1062-1047.

39. Utz JP, Limper AH, Kalra S, et al. Etanercept for the treatment of stage II and III progressive pulmonary sarcoidosis. Chest 2003; 124: 177-185.

40. Van den Brande JM, Braat $H$, van den Brink $G R$, et al. Infliximab but not etanercept induces apoptosis in lamina propria T-lymphocytes from patients with Crohn's disease. Gastroenterology 2003; 124: 1774-1785.

41. Costabel U. Sarcoidosis: clinical update. Eur Respir J 2001; 18: Suppl. 32, $56 \mathrm{~s}-68 \mathrm{~s}$.

42. Sharma OP. Pulmonary sarcoidosis: management. J Postgrad Med 2002; 48: 135-141.

43. Sharma OP. Renal sarcoidosis and hypercalcaemia. Eur Respir Mon 2005: 10, 32: 220-232. 